\title{
PERLINDUNGAN HUKUM TERHADAP KREDITOR APABILA OBJEK JAMINAN FIDUSIA TERNYATA HILANG DAN DEBITOR WANPRESTASI (STUDI KASUS DI PT. BANK PERKREDITAN RAKYAT DINAMIKA BANGUN ARTA SALATIGA)
}

\author{
Martin Anggiat Maranata Manurung \\ Jawade Hafidz
}

\begin{abstract}
ABSTRAK
Penelitian yang berjudul "Perlindungan Hukum Terhadap Kreditor Apabila Objek Jaminan Fidusia Ternyata Hilang Dan Debitor Wanprestasi (Studi Kasus di PT. Bank Perkreditan Rakyat Dinamika Bangun Arta Salatiga)" adalah untuk mengetahui bagaimana penyelesaian kredit bermasalah terhadap objek jaminan fidusia yang hilang dan apabila debitor wanprestasi pada PT. Bank Perkreditan Rakyat Dinamika Bangun Arta Salatiga dan untuk mengetahui sampai sejauh mana perlindungan hukumnya.

Penelitian ini menggunakan metode pendekatan yuridis empiris. Spesifikasi dalam penelitian ini bersifat deskriptif analitis, dimana sumber datanya adalah data primer dan data sekunder.

Penyelesaian kredit bermasalah dalam hal objek jaminan fidusia yang ternyata hilang dan apabila debitor wanprestasi pada PT. Bank Perkreditan Rakyat Dinamika Bangun Arta Salatiga ternyata dilakukan dengan cara yang sama yaitu : melakukan pendekatan secara kekeluargaan; melakukan penagihan secara langsung ke debitor; melakukan analisa ulang terhadap kredit; dan melakukan tindakan litigasi.

Perlindungan hukum terhadap kreditor dalam hal jaminan fidusia adalah sampai sejauh mana eksekusi dapat dilakukan. Apakah kreditor dalam posisi safety untuk melaksanakan eksekusi dengan dokumen pengikatan kredit dan agunan yang ada. Pengikatan agunan secara fidusia harus didaftarkan, dimana akta jaminan fidusia harus didaftarkan pada Kantor Fidusia Kementerian Hukum dan Hak Asasi Manusia Republik Indonesia, sehingga terbitlah Sertifikat Jaminan Fidusia yang mempunyai kekuatan eksekutorial yang sama dengan putusan pengadilan yang telah memperoleh kekuatan hukum yang tetap. Kreditor juga mempunyai hak untuk menjual benda yang menjadi objek jaminan fidusia melalui pelelangan umum serta melakukan pelunasan utang dari hasil penjualan, atau penjualan di bawah tangan yang dilakukan berdasarkan kesepakatan bersama antara para pihak, dimana penjualan secara sukarela ini biasanya melalui penyerahan secara sukarela dari debitor kepada bank untuk melunasi hutang debitor.
\end{abstract}

Kata Kunci : Perlindungan Hukum Kreditor Apabila Objek Jaminan Fidusia Ternyata Hilang Dan Debitor Wanprestasi

\section{A. Latar Belakang Masalah}

Upaya dalam mendapatkan investasi yang baik untuk ke depan, dibutuhkan pula modal yang besar, tidak dapat disangkal bahwa dalam upaya mendapatkan modal tersebut tidak jauh dari namanya lembaga keuangan bank. Bank adalah suatu badan usaha yang berbadan hukum yang bergerak di bidang jasa keuangan, yang dapat menghimpun dana dari masyarakat secara langsung dan menyalurkannya kembali ke masyarakat melalui pranata hukum perkreditan $^{1}$.

Pelaksanaan pemberian fasilitas kredit dari kreditor terhadap debitor pada umumnya dilakukan dengan mengadakan perjanjian, karena setiap kredit yang telah disetujui dan disepakati pemohon kredit wajib dituangkan ke dalam perjanjian kredit. Perjanjian kredit ini merupakan perjanjian pokok dimana menentukan batal atau tidaknya suatu perjanjian, kemudian juga sebagai bukti batasan hak dan kewajiban di antara kreditor dan debitor, setelah itu juga sebagai alat untuk melakukan pengawasan terhadap pelunasan hutang debitor. Perjanjian kredit

\footnotetext{
${ }^{1}$ Sentosa Sembiring, 2012, Hukum Perbankan, CV. Mandar Maju, Jakarta, hlm.18.
} tersebut sering kali diikuti oleh perjanjian tambahan yang berupa jaminan oleh pihak debitor kepada pihak kreditor. $^{2}$

Jaminan yang diberikan dalam rangka pemberian kredit dari kreditor kepada debitor sebagai perjanjian tambahan dalam arti, bila debitor tidak mampu melunasi hutangnya atau wanprestasi, maka jaminan akan disita yang kemudian akan dilelang untuk melunasi pinjaman yang tidak dapat dibayar oleh debitor. Pada umumnya jaminan kebendaan merupakan jaminan yang lazim dan dikuasai oleh Bank, karena mengingat hak kebendaan tersebut dapat dinilai dengan uang sehingga bila debitor tidak mampu melunasi hutangnya, jaminan segera dapat dieksekusi. Jaminan kebendaan yang dikenal di dalam hukum positif disamping Hak Tanggungan, Hipotik, Gadai: Jaminan Fidusia. $^{3}$

Undang-Undang Nomor 42 Tahun 1999 tentang Jaminan Fidusia selanjutnya disebut Undang-Undang

\footnotetext{
${ }^{2}$ Mariam Darus Badrulzaman, 1983, Perjanjian Kredit Bank, PT. Alumni, Bandung, hlm. 29.

${ }^{3}$ H. Salim HS, 2004, Perkembangan Hukum Jaminan Di Indonesia, PT. Raja Grafindo Persada, Jakarta, hlm. 21.
} 
Fidusia, pada pasal 1 angka (1) dikemukakan pengertian Fidusia: ${ }^{4}$

Jaminan fidusia merupakan tambahan, ketika perjanjian kredit berakhir maka dengan sendirinya perjanjian fidusia akan berakhir. Undang-Undang menentukan pembebanan benda dengan jaminan fidusia dibuat dengan akta notaris, agar jaminan fidusia mempunyai kepastian hukum, tidak hanya untuk menambah kepastian hukum jaminan fidusia perlu didaftarkan di kantor pendaftaran fidusia yang menghasilkan Sertifikat Jaminan Fidusia kepada penerima fidusia, dimana sertifikat tersebut mempunyai kekuatan hukum yang setara dengan putusan pengadilan yang telah memperoleh kekuatan hukum tetap, sehingga apabila debitor cidera janji, maka memudahkan penerima fidusia mempunyai hak untuk menjual benda yang menjadi objek jaminan fidusia atas kekuasaannya sendiri.

Berdasarkan latar belakang yang telah dikemukakan di atas, maka penulis tertarik untuk melakukan penelitian dan pembahasan lebih lanjut dengan judul: "Perlindungan Hukum Terhadap Kreditor Apabila Objek Jaminan Fidusia Ternyata Hilang Dan Debitor Wanprestasi (Studi Kasus di PT. Bank Perkreditan Rakyat Dinamika Bangun Arta Salatiga)".

\section{B. Rumusan Masalah}

Berdasarkan uraian yang menjadi alasan pemilihan judul sebagaimana tersebut di atas, maka dapat dirumuskan beberapa permasalahan sebagai berikut:

1. Bagaimanakah penyelesaian kredit bermasalah terhadap objek jaminan fidusia yang hilang dan apabila debitor wanprestasi pada PT. Bank Perkreditan Rakyat Dinamika Bangun Arta Salatiga?

2. Bagaimana perlindungan hukum terhadap kreditor (PT. Bank Perkreditan Rakyat Dinamika Bangun Arta Salatiga) apabila barang yang dijadikan jaminan fidusia ternyata objek tersebut hilang dan apabila debitor wanprestasi?

\section{Pembahasan}

\section{Tindakan Penyelesaian Kredit Bermasalah Apabila Objek Jaminan Fidusia Ternyata Hilang Dan Debitor Wanprestasi}

\footnotetext{
${ }^{4}$ Ibid., hlm. 55.
}

Tindakan penyelesaian atas objek jaminan fidusia yang ternyata hilang dan debitor wanprestasi yang dilakukan PT. Bank Perkreditan Rakyat Dinamika Bangun Arta Salatiga adalah dengan cara: ${ }^{5}$

a. Melakukan pendekatan secara kekeluargaan

Bank melakukan pendekatan secara kekeluargaan (person to person) yang dilakukan oleh staf marketing, Kepala Bagian Kredit dan Direktur untuk melakukan penyelesaian kredit bermasalah yang disebabkan wanprestasi ini akan dilakukan negosiasi dengan menawarkan kemudah-mudahan kepada debitor agar kredit bermasalah ini menjadi terselesaikan.

b. Melakukan penagihan secara langsung ke debitor. Tindakan ini dilakukan oleh petugas khusus (staf internal bank) yang terus menerus melakukan penagihan ke tempat debitor maupun ke pemilik jaminan secara tertib dan menjunjung tinggi etika yang diterapkan oleh PT. Bank Perkreditan Rakyat Dinamika Bangun Arta Salatiga.

c. Melakukan analisa ulang terhadap kredit

Ada beberapa cara atau jalan yang ditawarkan PT. Bank Perkreditan Rakyat Dinamika Bangun Arta Salatiga kepada debitor yaitu:

(1) Memperpanjang jangka waktu kredit dengan merubah jadwal;

(2) Merubah jenis kredit modal kerja;

(3) Pembebasan tunggakan bunga atau tunggakan angsuran;

(4) Menurunkan suku bunga kredit;

(5) Pengambilalihan aset atau jaminan pokok sesuai ketentuan

d. Melakukan tindakan litigasi

Tindakan litigasi ini dilakukan apabila cara penyelesaian dengan metode kekeluargaan atau negosiasi tidak tercapai.

2. Perlindungan Hukum Terhadap Kreditor (PT. Bank Perkreditan Rakyat Dinamika Bangun Arta Salatiga)

Perlindungan hukum terhadap kreditor dalam jaminan fidusia adalah sampai sejauh mana eksekusi dapat dilakukan. Apakah kreditor dalam posisi safety untuk melaksanakan eksekusi dengan dokumen pengikatan dan agunan yang ada. Pengikatan agunan secara fidusia harus didaftarkan, dimana akta jaminan fidusia harus didaftarkan pada Kantor Fidusia

\footnotetext{
${ }^{5}$ Wawancara dengan Hendy Wahyu Indras Sakti sebagai Kepala Bagian Kredit PT. Bank Perkreditan Rakyat Dinamika Bangun Arta Salatiga, tanggal 25 Februari 2017.
} 
Kementerian Hukum dan Hak Asasi Manusia Repubik Indonesia, sehingga terbitlah Sertifikat Jaminan Fidusia. Sertifikat jaminan fidusia ini merupakan salinan dari Buku Daftar Fidusia yang memuat catatan tentang hal-hal yang dimuat dalam pernyataan pendaftaran. Dalam sertifikat jaminan fidusia mencantumkan kalimat "DEMI KETUHANAN YANG MAHA ESA", sehingga sertifikat jaminan fidusia tersebut mempunyai kekuatan eksekutorial yang sama dengan putusan pengadilan yang telah memperoleh kekuatan hukum yang tetap. Apabila debitor wanprestasi maka kreditor mempunyai hak untuk melaksanakan titel eksekutorial sebagaimana tercantum dalam sertifikat jaminan fidusia. Kreditor juga mempunyai hak untuk menjual benda yang menjadi objek jaminan fidusia melalui pelelangan umum serta pelunasan piutang dari hasil penjualan atau penjualan di bawah tangan yang dilakukan berdasarkan kesepakatan bersama antara para pihak, penjualan secara sukarela ini di PT. Bank Perkreditan Rakyat Dinamika Bangun Arta Salatiga biasanya dilakukan melalui penyerahan secara sukarela dari debitor untuk melunasi hutang debitor dengan cara menjual agunan dengan harga yang disepakati oleh debitor dan PT. Bank Perkreditan Rakyat Dinamika Bangun Arta Salatiga dengan harga tertinggi yang mana hasil penjualannya adalah untuk melunasi hutang debitor. Apabila harga lebih tinggi dan ada sisa maka sisa hasil penjualan akan diserahkan kepada debitor. ${ }^{6}$

Demi memenuhi asas publisitas, maka UndangUndang Nomor 42 Tahun 1999 tentang Jaminan Fidusia mengatur hal baru yaitu mengenai pendaftaran jaminan fidusia guna memberikan kepastian hukum tidak saja kepada para pihak tetapi juga kepada pihak ketiga serta menimbulkan hak untuk didahulukan bagi penerima fidusia terhadap kreditor lainnya.

Berkaitan dengan dibuatnya suatu aturan hukum agar adanya ketertiban, keteraturan dan memberikan kepastian hukum khususnya bagi pelaku usaha dengan adanya Undang-Undang Nomor 42 Tahun 1999 tentang Jaminan Fidusia, artinya bahwa dengan hadirnya Undang-Undang Nomor 42 Tahun 1999 tentang Jaminan Fidusia memberikan kepastian hukum bagi pelaku usaha dengan menjadikan jaminan fidusia sebagai salah satu sumber pembiayaan guna menunjang dinamika kegiatan usaha, ternyata yang terjadi sebaliknya, yaitu ketidakteraturan dan ketidakpastian hukum atau legal uncertainty.

\footnotetext{
${ }^{6}$ Wawancara dengan Hendy Wahyu Indras Sakti sebagai Kepala Bagian Kredit PT. Bank Perkreditan Rakyat Dinamika Bangun Arta Salatiga, tanggal 25 Februari 2017.
}

Dalam hal ini PT. Bank Perkreditan Rakyat Dinamika Bangun Arta Salatiga telah menerapkan peraturan pendaftaran fidusia yang sesuai dengan ketentuan, dimana bahwa setiap jaminan fidusia baik atas kendaraan roda dua maupun roda empat wajib didaftarkan, karena dengan didaftarkannya jaminan fidusia maka kreditor memiliki hak preferen. Hanya saja semua jaminan yang diserahkan tidak diasuransikan. ${ }^{7}$

\section{Kesimpulan}

Berdasarkan permasalahan yang dikemukakan di atas dan hasil analisis data yang diperoleh dari penelitian, diambil kesimpulan sebagai berikut:

1. Penyelesaian kredit bermasalah dalam hal objek jaminan fidusia yang ternyata hilang dan apabila debitor wanprestasi pada PT. Bank Perkreditan Rakyat Dinamika Bangun Arta Salatiga dilakukan dengan cara yang sama yaitu:

a. Melakukan pendekatan secara kekeluargaan

b. Melakukan penagihan secara langsung ke debitor

c. Melakukan analisa ulang terhadap kredit

d. Melakukan tindakan litigasi

2. Perlindungan hukum terhadap kreditor dalam hal jaminan fidusia adalah sampai sejauh mana eksekusi dapat dilakukan. Pada PT. Bank Perkreditan Rakyat Dinamika Bangun Arta Salatiga, akta jaminan fidusia dibuat secara notariil, kemudian didaftarkan pada Kantor Fidusia Kementerian Hukum dan Hak Asasi Manusia Republik Indonesia secara online, lalu terbitlah Sertifikat Jaminan Fidusia yang mempunyai kekuatan eksekutorial yang sama dengan putusan pengadilan yang telah memperoleh kekuatan hukum yang tetap. Kreditor juga mempunyai hak untuk menjual benda yang menjadi objek jaminan fidusia melalui pelelangan umum, serta pelunasan piutang dari hasil penjualan (penjualan di bawah tangan dilakukan berdasarkan kesepakatan bersama antara para pihak), melalui penyerahan secara sukarela dari debitor kepada kreditor untuk melunasi hutang debitor.

\section{DAFTAR PUSTAKA}

\section{A. Buku - Buku}

\footnotetext{
${ }^{7}$ Wawancara dengan Dani Satriawan sebagai Direktur Utama PT. Bank Perkreditan Rakyat Dinamika Bangun Arta Salatiga, tanggal 25 Februari 2017.
} 
D.H.M. Meuwissen., 1985, Rechtsteorie dalam Van Apeldoorn's Inleiding Tot De Studie Van Het Jamiederlandse Recht, W.E.J. Tjeenk Willink, Zwolle.

H. Salim HS., 2004, Perkembangan Hukum Jaminan Di Indonesia, PT Raja Grafindo Persada, Jakarta.

Ignatius Ridwan Widyadharma., 1995, Hukum Perbankan, CV Ananta, Semarang.

Mariam Darus Badrulzaman., 1983, Perjanjian Kredit Bank, Alumni, Bandung.

Sentosa Sembiring., 2012, Hukum Perbankan, CV. Mandar Maju, Jakarta.

Sutrisno Hadi., 2000, Metodelogi Research Jilid 1, Abdi Offset, Yogyakarta.
Wawancara dengan Dani Satriawan sebagai Direktur Utama PT. Bank Perkreditan Rakyat Dinamika Bangun Arta Salatiga, tanggal 25 Februari 2017.

Wawancara dengan Hendy Wahyu Indras Sakti sebagai Kepala Bagian Kredit PT. Bank Perkreditan Rakyat Dinamika Bangun Arta Salatiga, tanggal 25 Februari 2017

\section{B. Peraturan Perundang-Undangan}

Kitab Undang-Undang Hukum Perdata.

Undang-Undang Republik Indonesia Nomor 10 Tahun 1998 tentang Perubahan Atas Undang-Undang Republik Indonesia Nomor 7 Tahun 1992 Tentang Perbankan.

Undang-Undang Republik Indonesia Nomor 42 Tahun 1999 Tentang Jaminan Fidusia. 